Bolm Inst. oceanogr., S Paulo, $31(2): 5-7,1982$

\title{
DISTRIBUTION AND ABUNDANCE OF SKIPJACK (KATSUWONUS PELAMIS) LARVAE IN EASTERN BRAZILIAN WATERS
}

Yasunobu MATSUURA

Instituto Oceanogräfico da Universidade de São Paulo

Synopsis

Based on data from two ichthyoplankton surveys carried out off the eastern Brazilian coast in June and November-December 1978, the larval distribution of skipjack is discussed. Skipjack larvae were more abundant in the November-December cruise (southem hemisphere spring). They occurred mainly at stations near the margin of the continental shelf or over seamounts. Out of 240 specimens of scombmid larvae collected in this area, skipjack lamae comprised only 10.4\% (25 specimens), whereas the most abundant Zarvae were Thunnus spp. with $68.8 \%$ (165 specimens).

\section{Introduction}

Skipjack tuna is one of the most important commercial scombrid fish exploited in the world ocean with a yield of 699 thousand metric tons in 1979 (FAO, 1980). In spite of the world-wide large catches, the stock of this species in the Brazilian coast is considered underexploited (Matsuura, 1982). In order to evalute the fishery potential of skipjack and to search for a new fishing area, the International Commission for the Conservation of Atlantic Tunas (ICCAT) started the International Skipjack Year Programme in 1979. As one of the member countries of ICCAT, Brazil participates on several survey programmes which the Instituto Oceanográfico da Universidade de São Paulo undertakes off the Brazilian coast. The objective of the larval survey team of this programme is to study the density of skipjack larvae in the area where no commercial skipjack fishery is operating. This report describes a part of the results obtained from the survey cruises made off the eastern Brazilian coast in 1978 .

\section{Material and methods}

Two ichthyoplankton surveys were conducted aboard the R/V "Prof. W. Besnard" from 6 to 19 June and from 28 November to 10 December, 1978 off the eastern Brazilian coast. Each cruise covered the same survey area between Corumbau (Lat. $\left.17^{\circ} \mathrm{S}\right)$ and Cabo Frio $\left(23^{\circ} \mathrm{S}\right)$, in which 64 sampling stations were occupied (Fig. 1). Distance between stations was 30 nautical miles. Routine Bongo net sampling were Publ. n! 534 do Inst. oceanogr. da Usp. made following the method described in Matsuura (1979). Al1 fish eggs and larvae were sorted from plankton samples, and then scombrid larvae were separated. The identification of Katsuwonus pelamis larvae was made based on descriptions and figures of Matsumoto (1958) and Ueyanagi \& Watanabe (1964). The number of larvae taken at each station was

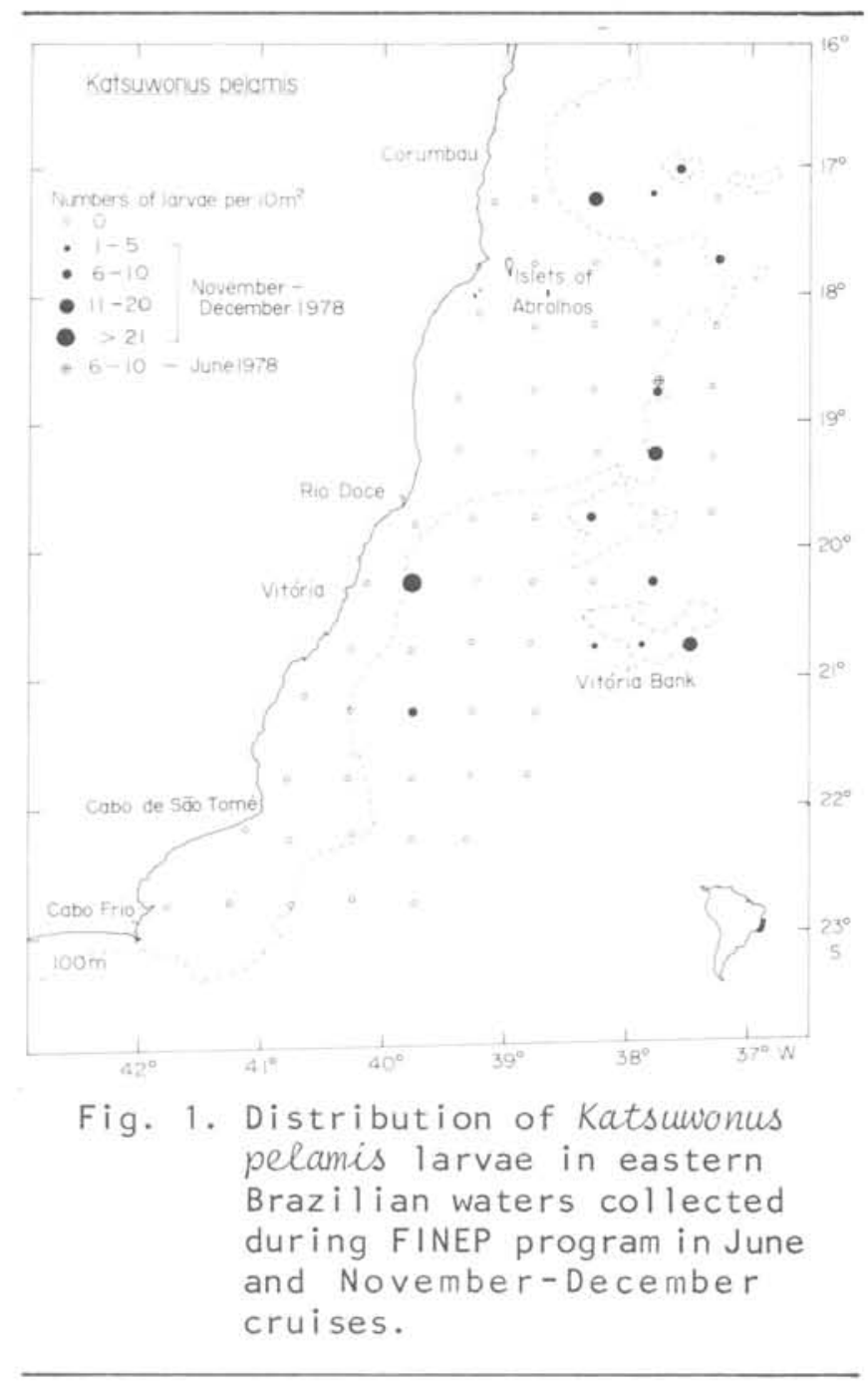


transformed into the number per $10 \mathrm{~m}^{2}$ of sea surface by the following expression:

$$
y=\frac{d \cdot x}{V} \cdot 10,
$$

where $\mathrm{y}=$ number of larvae per $10 \mathrm{~m}^{2}$ of sea surface, $d=$ depth of tow in meters, $\mathrm{V}=$ volume of water filtered by net and $\mathrm{x}=$ number of larvae collected.

\section{Results and discussion}

The skipjack larvae were collected mainly during the November-December cruise, only one specimen being taken during the June cruise (Tab. I). The proportion of skipjack larvae in relation to the total scombrid larvae was $10.4 \%$ (25 specimens), the second most abundant species after Thunnus spp. larvae, which were the dominant group of $68.8 \%$ (165 specimens).

The continental shelf of the eastern Brazilian coast is approximately 30 to $40 \mathrm{n} . \mathrm{m}$. wide, with the exception of the Abrolhos region where it extends offshore as far as $150 \mathrm{n.m}$. from the coast, named here the Abrolhos hump of the continental shelf. The Brazil Current coming from the north runs southward along the continental slope and encounters this shallow continental shelf at 1 at. $17^{\circ} 30^{\prime} \mathrm{s}$. The influence of the Abrolhos hump on the flow of the Brazil Current is not yet known.

Skipjack larvae were taken mainly at stations near the margin of the continental shelf or over seamounts (Fig. 1).
Two larval concentrations were observed: one off the northern margin of the Abrolhos hump and another along the southeastern margin plus on the vitória seamount, south of the Abrolhos hump.

Larvae of Katsuwonus pelamis were collected in temperatures ranging from 25.3 to $26.7^{\circ} \mathrm{C}$ with mean temperature of $25.9^{\circ} \mathrm{C}$ and salinities ranging from 37.0 to $37.3 \%$ with mean salinity of 37.2 $\%$, typically tropical high saline waters.

The occurrence of scombrid larvae in this area was initially reported by Nishikawa et al. (1978), who studied the materials collected by the $\mathrm{R} / \mathrm{V}$ "Shoyo-Maru" and "Shunyo-Maru" from 1956 to 1975. They found a high concentration of skipjack larvae in the $5^{\circ}$ block $\left(10-15^{\circ} \mathrm{S}: 35-40^{\circ} \mathrm{W}\right)$ during the January-March season. They did not conduct plankton sampling during winter season off the Brazilian coast, but the results of our June cruise suggest that the spawning activity of skipjack is low in winter.

Recently Kikawa \& Nishikawa (1980) reviewed the larval occurrence of yellowfin and skipjack tunas in the Atlantic Ocean, based mainly on the data presented by Nishikawa et al.

(1978) with some additional informations. They showed the most of the skipjack larvae were collected in temperatures ranging from 24 to $28^{\circ} \mathrm{C}$, but one larva was taken in temperature $22.6^{\circ} \mathrm{C}$ in the south Atlantic.

Matsuura \& Sato (1981) showed the

Table 1 - Occurrence of skipjack larvae in the cruises of June and November-December of 1978

\begin{tabular}{|c|c|c|c|c|c|c|c|c|}
\hline \multirow{2}{*}{$\begin{array}{l}\text { Sample } \\
\text { N: }\end{array}$} & \multirow[b]{2}{*}{ Date } & \multirow[b]{2}{*}{ Time } & \multicolumn{2}{|c|}{ Position } & \multirow{2}{*}{$\begin{array}{l}\text { Station } \\
\text { depth }(m)\end{array}$} & \multirow{2}{*}{$\begin{array}{l}\text { No of } \\
\text { larvae }\end{array}$} & \multirow{2}{*}{$\begin{array}{c}\text { Volume of water } \\
\text { filtered }\left(\mathrm{m}^{3}\right)\end{array}$} & \multirow{2}{*}{$\begin{array}{c}\text { No of } \\
\text { 1arvae/10 } \mathrm{m}^{2}\end{array}$} \\
\hline & & & Lat. (S) & Long. (w) & & & & \\
\hline 2437 & $17 / 06 / 78$ & $01: 40$ & $18^{\circ} 48^{\prime} 3$ & $37^{\circ} 44 \cdot 8$ & 3200 & 1 & 200 & 10.0 \\
\hline 2470 & $01 / 12 / 78$ & $20: 45$ & $21^{\circ} 15^{\circ} 0$ & $39^{\circ} 45^{\prime} 0$ & 1850 & 1 & 278 & 7.2 \\
\hline 2477 & $03 / 12 / 78$ & $00: 15$ & $20^{\circ} 45^{\prime} 0$ & $38^{\circ} 15^{\circ} 0$ & 3000 & 1 & 340 & 5.9 \\
\hline 2478 & $03 / 12 / 78$ & $03: 35$ & $20^{\circ} 44 \cdot 8$ & $37^{\circ} 51 \cdot 3$ & 56 & 1 & 239 & 2.1 \\
\hline 2479 & $03 / 12 / 78$ & $13: 30$ & $20^{\circ} 45^{\prime} 0$ & $37^{\circ} 27^{\prime} 9$ & 1400 & 2 & 321 & 12.4 \\
\hline 2480 & $03 / 12 / 78$ & $17: 30$ & $20^{\circ} 15^{\prime} 3$ & $37^{\circ} 45^{\prime} 5$ & 2000 & 1 & 309 & 6.5 \\
\hline 2484 & $04 / 12 / 78$ & $08: 30$ & $20^{\circ} 15^{\prime} 0$ & $39^{\circ} 45^{\prime} 0$ & 1350 & 5 & 300 & 31.0 \\
\hline 2489 & $06 / 12 / 78$ & $08: 40$ & $19^{\circ} 45^{\prime} 0$ & $38^{\circ} 16^{\prime} 4$ & 68 & 2 & 118 & 10.6 \\
\hline 2493 & $06 / 12 / 78$ & $22: 38$ & $19^{\circ} 15^{\circ} 0$ & $37^{\circ} 45^{\circ} 0^{\circ}$ & 3400 & 2 & 259 & 15.4 \\
\hline 2500 & $08 / 12 / 78$ & $01: 20$ & $18^{\circ} 45^{\prime} 5$ & $37^{\circ} 43 \cdot 8$ & 3200 & 1 & 283 & 7.1 \\
\hline 2510 & $09 / 12 / 78$ & $13: 40$ & $17^{\circ} 43 \cdot 3$ & $37^{\circ} 15^{\prime} 0$ & 3300 & 1 & 273 & 7.3 \\
\hline 2512 & $09 / 12 / 78$ & $21: 00$ & $17^{\circ} 0115=$ & $37^{\circ} 33^{\prime} 0$ & 50 & 2 & 134 & 6.8 \\
\hline 2513 & $10 / 12 / 78$ & $07: 35$ & $17^{\circ} 21 \cdot 2$ & $37^{\circ} 46^{\prime} \cdot 2$ & 1800 & 1 & 467 & 4.3 \\
\hline 2514 & $10 / 12 / 78$ & $11: 05$ & $17^{\circ} 15^{\prime} 0$ & $38^{\circ} 15^{\circ} 0$ & 1900 & 4 & 488 & 16.4 \\
\hline
\end{tabular}


occurrences of skipjack larvae off the Cabo Frio $\left(23^{\circ} \mathrm{S}\right)$ and São Francisco do Sul $\left(26^{\circ} \mathrm{S}\right)$ in the January 1976 cruise. Since the ichthyoplankton surveys conducted in the Brazilian coast indicated that the skipjack larvae have been taken during spring and summer seasons and the study of maturity stages of gonads also showed the presence of matured skipjack during summer season (Zavala-Camin, 1978), we can conclude that the main spawning season of the skipjack in the Brazilian coast is during spring-summer season.

\section{Acknowledgments}

Financial support for this investigation came from FINEP (Financiadora de Estudos e Projetos S.A.). I thank all who assisted the sampling and sorting the materials. Special thanks go to the Captain Adilson L. Gama and crew of the R/V "Prof. W. Besnard". Dr. W. H. Bayliff of the Inter-American Tropical Tuna Commission kindly reviewed the manuscript. This paper was presented at the 1981 SCRS meeting of ICCAT in Madrid.

\section{References}

FAO. 1980. Catch and landings 1979. Yb. Fish. Statist., 48:1-384.

KIKAWA, S. \& NISHIKAWA, Y. 1980. Distribution of larvae of yellowfin tuna and skipjack in the Atlantic Ocean (preliminary). Collective Vol. Sci. Pap., ICCAT, Madrid, 9:138-142.

MATSUMOTO, W. M. 1958. Description and distribution of larvae of four species of tuna in Central Pacific waters. Fishery Bul1. Fish Wildl. Serv. U.S., ser. Fisheries, $58(128): 31-72$.
MATSUURA, Y. 1979. Distribution and abundance of eggs and larvae of the Brazilian sardine, Sardinella brasiliensis, during 1974-75 and 197576 seasons. Bull. Jap. Soc. Fish. Oceanogr., 34:1-12.

1982. Perspectiva de pesca de bonitos e atuns no Brasil. Ciênc. Cult., S Paulo, 34(3):333-339.

$$
\text { \& SATO, G. 1981. Distri- }
$$

bution and abundance of scombrid larvae in southern Brazilian waters. Bu11. mar. Sci., 31(4):824-832.

NISHIKAWA, Y.; KIKAWA, S.; HONMA, M. \& UEYANAGI, S. 1978. Distribution atlas of larval tunas, billfishes and related species. Results of larval surveys by R/V "Shunyo-Maru" and "Shoyo-Maru", 1956-1975. Far Seas Fish. Res. Lab., S. Ser., 9:1-99.

UEYANAGI, S. \& WATANABE, H. 1964. Methods of identification of larvae of tunas and billfishes (II). Nankai Reg. Fish. Res. Lab., Materials for tuna fisheries research council. 16p. (in Japanese).

ZAVALA-CAMIN, L. A. 1978. Anotaciones sobre la presencia del 1 istado en el sudeste y sur del Brasil. Collective Vol. scient. Pap., ICCAT, Madrid, 7: 82-83.

(Manuscript received on 23/Apr./1982; accepted on 13/Aug./1982) 